\title{
Elevated carbon dioxide and temperature effects on rooting behaviour of grape cuttings
}

\author{
SHRUTHI REDDY. L. ${ }^{1 *}$, GOPALA KRISHNA REDDY. A. ${ }^{2}$, VANAJA. M. ${ }^{2}$, MARUTHI. V. ${ }^{2}$ and \\ VANAJA LATHA. K. ${ }^{3}$
}

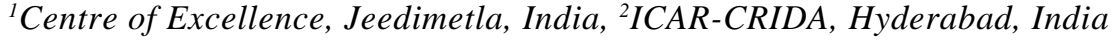 \\ ${ }^{3}$ SKL Telangana State Horticultural University, Hyderabad, India \\ *Corresponding Author email: lattupallyshruthireddy@gmail.com
}

\begin{abstract}
An experiment was laid out to study the impact of $\mathrm{eCO}_{2}(550 \mathrm{ppm})$, eT $\left(+3^{\circ} \mathrm{C}\right)$ and their interaction $\left(\mathrm{eCO}_{2}+\mathrm{eT}\right)$ on rooting behaviour of cuttings of three grape varieties- Thompson Seedless, Bangalore Blue, and Dogridge in FATE and OTC facilities. Observations were recorded at 50 and 80 days after planting (DAP) and root growth data was recorded and analysed using WinRHIZO root scanner and its software. Analysis revealed that, among the selected grape varieties, Thompson Seedless cuttings has shown highest number of roots, root volume and dry biomass under $\mathrm{eCO}_{2}$ and $\mathrm{eCO}_{2}+\mathrm{eT}$ conditions, while total root length and root length density were highest with Bangalore Blue. Under eT condition, Bangalore Blue showed highest number of roots, total root length and root length density, while root volume and dry biomass was highest with Thompson Seedless. The per se values of root parameters under all conditions and their response to $\mathrm{eCO}_{2}$ was lowest with Dogridge. Though eT condition reduced all the root parameters, their performance improved under $\mathrm{eCO}_{2}+\mathrm{eT}$ indicating the presence of higher concentration of $\mathrm{CO}_{2}$ reduced the ill effects of high temperature. Overall, $\mathrm{eCO}_{2}$ and $\mathrm{eCO}_{2}+\mathrm{eT}$ conditions improved root parameters of grape varieties, while eT reduced them as compared to their performance under ambient condition and varietal variation is significant.
\end{abstract}

Key words: $\mathrm{eCO}_{2}$, root growth, stem cuttings, varieties, WinRHIZO

Climate change is a global issue and expected to impact agricultural productivity and its quality. The changing patterns of climatic parameters like rise in atmospheric $\mathrm{CO}_{2}$, temperature, changes in precipitation patterns, UV radiation and higher incidence of extreme weather events such as floods, heat waves are emerging as major threats for agricultural production. The climate change is a result of emission of greenhouse gases such as $\mathrm{CO}_{2}, \mathrm{CH}_{4}, \mathrm{~N}_{2} \mathrm{O}$ etc., which will cause atmosphere warming (IPCC 2007) and will affect all levels of life from species to ecosystem. Atmospheric concentrations of $\mathrm{CO}_{2}$ have steadily increased from approximately 315 ppm in 1959 to a record high concentration of $417.2 \mathrm{ppm}$ in May 2020. At this rate of increase, the concentration of $\mathrm{CO}_{2}$ is projected to reach between 700 and $1000 \mathrm{ppm}$ by 2100 (IPCC 2014). Rising concentrations of carbon dioxide will potentially increase global average surface temperatures by $1.4-5.8^{\circ} \mathrm{C}$. Therefore, it is important to quantify the interactive effects of increasing $\mathrm{CO}_{2}$ and temperature on crop production. Grapes (Vitis vinifera L.) are sensitive to different environmental factors, including temperature, water availability and $\mathrm{CO}_{2}$. Like other $\mathrm{C}_{3}$ plants, grapevine photosynthesis is $\mathrm{CO}_{2}$ limited (Mullins et al., 1992) and any increase of atmospheric $\mathrm{CO}_{2}$ concentration could enhance accumulation of vegetative biomass and increase fruit yield (Bowes 1993; Rogers et al., 1994). It is observed that in the future grape yield increase as compared to the current climate (Kadbhane and Manekar (2020). Impact analyses of plant responses to elevated atmospheric $\mathrm{CO}_{2}$ have focused largely on aboveground processes and very limited studies were on root growth and development especially with fruit crops. It is necessary to understand the response of roots towards elevated $\mathrm{CO}_{2}$ condition as roots are interface between the lithosphere and biosphere. Root health in crop plants will play a major role in providing sustainable productivity as it enables to cope with changed climatic conditions. Keeping this in view the present research work was carried 
out with the objective to study the effect of elevated carbon dioxide and temperature on rooting behaviour of grape cuttings as well as variability in response of three popular grape cultivars.

\section{MATERIALS AND METHODS}

\section{Plant materials}

Hard wood stem cuttings of $25-30 \mathrm{~cm}$ length having 5-6 nodes of three popular grape varieties i.e. Thompson Seedless, Bangalore Blue, Dogridge were collected from the winter pruning of grape plants. Hard wood stem cuttings were treated with standard $1500 \mathrm{ppm}$ IBA (Lab grade) solution and planted in poly bags. The poly bags are of $23 \times 12 \times 12 \mathrm{~cm}$ and filled with potting mixture of $\mathrm{FYM}+$ red soil in 1:1 proportion and 15 number of cuttings each were exposed to ambient control, $\mathrm{eCO}_{2}$, eT and $\mathrm{eCO}_{2}+\mathrm{eT}$ conditions. The planted cuttings were kept under specially designed Open Top Chambers (OTC) and Free Air Temperature Enrichment (FATE) facilities in rabi 2017 at ICAR-CRIDA. The observations were recorded on three cuttings of each variety from all the conditions (ambient control, $\mathrm{eCO}_{2}$, eT and $\mathrm{eCO}_{2}+\mathrm{eT}$ ) on number of roots, fresh and dry weight of roots $\left(\mathrm{g} \mathrm{pl}^{-1}\right)$, root volume $\left(\mathrm{ml} \mathrm{pl}^{-1}\right)$, total root length $(\mathrm{cm})$, root diameter $(\mathrm{mm})$ and root length density at 50 and 80 days after planting (DAP).

\section{Treatments and experimental conditions}

To study the rooting pattern, the cuttings planted in polybags were exposed to elevated carbon dioxide of $550 \mathrm{ppm}$ in OTCs and elevated temperature (ambient $\left.+3^{\circ} \mathrm{C}\right)$, elevated carbon dioxide $(550 \mathrm{ppm})+$ elevated temperature in FATE facility. In OTC $(3 \times 3 \times 3$ $\mathrm{m})$ the desired levels of $\mathrm{CO}_{2}(550 \mathrm{ppm})$ concentration was maintained by continuous injection of $\mathrm{CO}_{2}$ into the plenum of OTCs, where it was mixed with air from air compressor before entering chamber and the set level of $\mathrm{CO}_{2}$ concentration was maintained with the help of solenoid valves, rotometers, programme Logic Control (PLC) and Supervisory Control and Data Acquisition (SCADA) software.

Free Air Temperature Elevation (FATE) facility consisting of six rings fitted with 24 arrays of $2000 \mathrm{~W}$ capacity ceramic infrared heaters above the canopy to maintain elevated crop canopy temperature (eT) of ambient $+3^{\circ} \mathrm{C}$. Among these, three rings were also provided with $\mathrm{CO}_{2}$ release system at $0.3 \mathrm{~m}$ height from base of the ring to study the interactive effects of temperature and $\mathrm{CO}_{2}\left(\mathrm{eT}+\mathrm{eCO}_{2}\right)$. The polyurethane (PU) tubing with perforations releases the $\mathrm{CO}_{2}$ within the ring to maintain the elevated concentration of $550 \mathrm{ppm}$. The $\mathrm{CO}_{2}$ in turn regulated by SCADA based control system linked with $\mathrm{CO}_{2}$ analyser, wind direction and wind speed. The ambient control was maintained without any enhancement of $\mathrm{CO}_{2}$ and temperature. WinRHIZO is an image analysis system specially designed for root measurement in different forms. The cuttings were harvested at 50 and 80 DAP and the roots were thoroughly washed to remove all soil particles. Scanning and image analysis was carried out using WinRHIZO root scanner (LA-1600) for root characteristics and the root morphology and architecture measurements such as total root length, root diameter, root length density and root volume were done by WinRHIZO program.

\section{RESULTS AND DISCUSSION}

Understanding the dynamics of crop roots is important from the point of view of management of available resources to increase the productivity of crops. Root parameters like number of roots, fresh and dry weight of roots, root volume, total root length, root diameter and root length density of three grape varieties were recorded at 50 and 80 days after planting under ambient control, $\mathrm{eCO}_{2}$, eT and $\mathrm{eCO}_{2}+\mathrm{eT}$ conditions.

\section{Root number}

At 50 DAP, Thompson Seedless $(10.2 \pm 0.182)$ and Dogridge $(6.3 \pm 0.54)$ showed maximum number of roots under $\mathrm{eCO}_{2}+\mathrm{eT}$, whereas in Bangalore Blue the maximum number of roots were found under eT $(10.3 \pm 0.23)$ condition. While at $80 \mathrm{DAP}$, all the three varieties have shown highest number of roots under $\mathrm{eCO}_{2}$ condition (Fig.1a). Among the three grape varieties, Thompson Seedless has shown higher number of roots under $\mathrm{eCO}_{2}$ and $\mathrm{eCO}_{2}+\mathrm{eT}$, while Bangalore Blue under eT and Dogridge under ambient conditions (Fig.1a).

At 50 DAP, increase in number of roots was 105 per cent $\left(\mathrm{eCO}_{2}\right), 216$ per cent (eT), and 225 per cent $\left(\mathrm{eCO}_{2}+\mathrm{eT}\right)$ in Thompson Seedless as compared with the ambient condition (Fig.1b). In Bangalore Blue there was 21, 121 and 79 per cent increase at $\mathrm{eCO}_{2}$, eT, and $\mathrm{eCO}_{2}+\mathrm{eT}$, respectively over the control. Whereas, no response for 

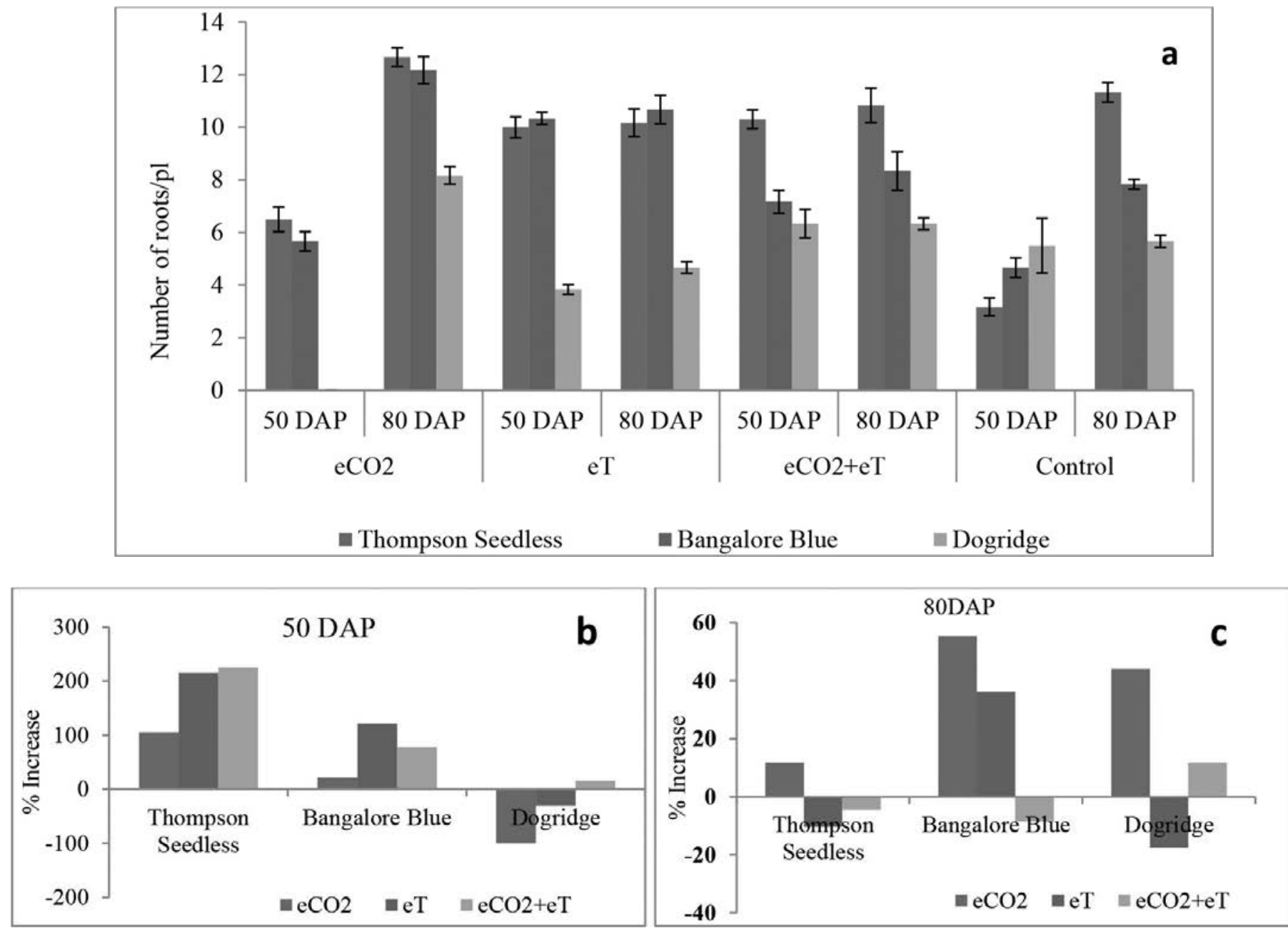

Fig. 1: (a) Number of roots of grape varieties under $\mathrm{eCO}_{2}$, eT, eCO $+\mathrm{eT}$ and control conditions at 50 and 80 DAP; Percentage increase in number of roots over control (b). at 50 DAP and (c). at 80 DAP

number of roots under $\mathrm{eCO}_{2}$ was observed with Dogridge while eT condition decreased it by 30 per cent, however, $\mathrm{CO}_{2}$ in combination with eT $\left(\mathrm{eCO}_{2}+\mathrm{eT}\right)$ increased root number by 15 per cent over ambient control (Fig.1b).

At 80 DAP, $\mathrm{eCO}_{2}$ has shown 12, 55 and 14 per cent increase in number of roots in Thompson Seedless, Bangalore Blue and Dogridge, respectively over control. While eT has shown a decrease of 10 and 18 per cent in Bangalore Blue and Dogridge, respectively while an increase of 30 per cent was recorded with Thompson Seedless over control. At $\mathrm{eCO}_{2}+\mathrm{eT}$ there was a decrease in number of roots of 4 and 9 per cent in Thompson Seedless and Bangalore Blue respectively while Dogridge showed 12 per cent increase in root number over control (Fig. 1c).

Root growth of most of the crops is enhanced under elevated atmospheric $\mathrm{CO}_{2}$ (Rogers et al., 1994;
Pritchard and Amthor, 2005), often to a greater extent than leaves, stem, and reproductive structures (Norby et al., 2001 and Kimball et al., 2002). According to Madhu and Jerry (2015), high $\mathrm{CO}_{2}$ might have inhibited the growth at early stage of crop but due to adoptive mechanism to high $\mathrm{CO}_{2}$ plants were recovered and responded physiologically at later stage. This is in accordance with Dogridge cuttings under $\mathrm{eCO}_{2}$ at 50 DAP. The $\mathrm{eCO}_{2}$ increases the carbon flow to the rhizosphere by increasing photosynthetic activity which in turn improves root production in plants (Rajkumar et al., 2013). More roots at all depths of the soil profile have been observed in sorghum when exposed to elevated $\mathrm{CO}_{2}$ (Chaudhuri et al., 1986).

\section{Total root length $(\mathrm{cm})$}

At 50DAP, Thompson Seedless (309.0 \pm 30.4 $\mathrm{cm})$ and Bangalore Blue $(365.4 \pm 24.5 \mathrm{~cm})$ have shown higher root length under $\mathrm{eCO}_{2}+\mathrm{eT}$ while Dogridge has 

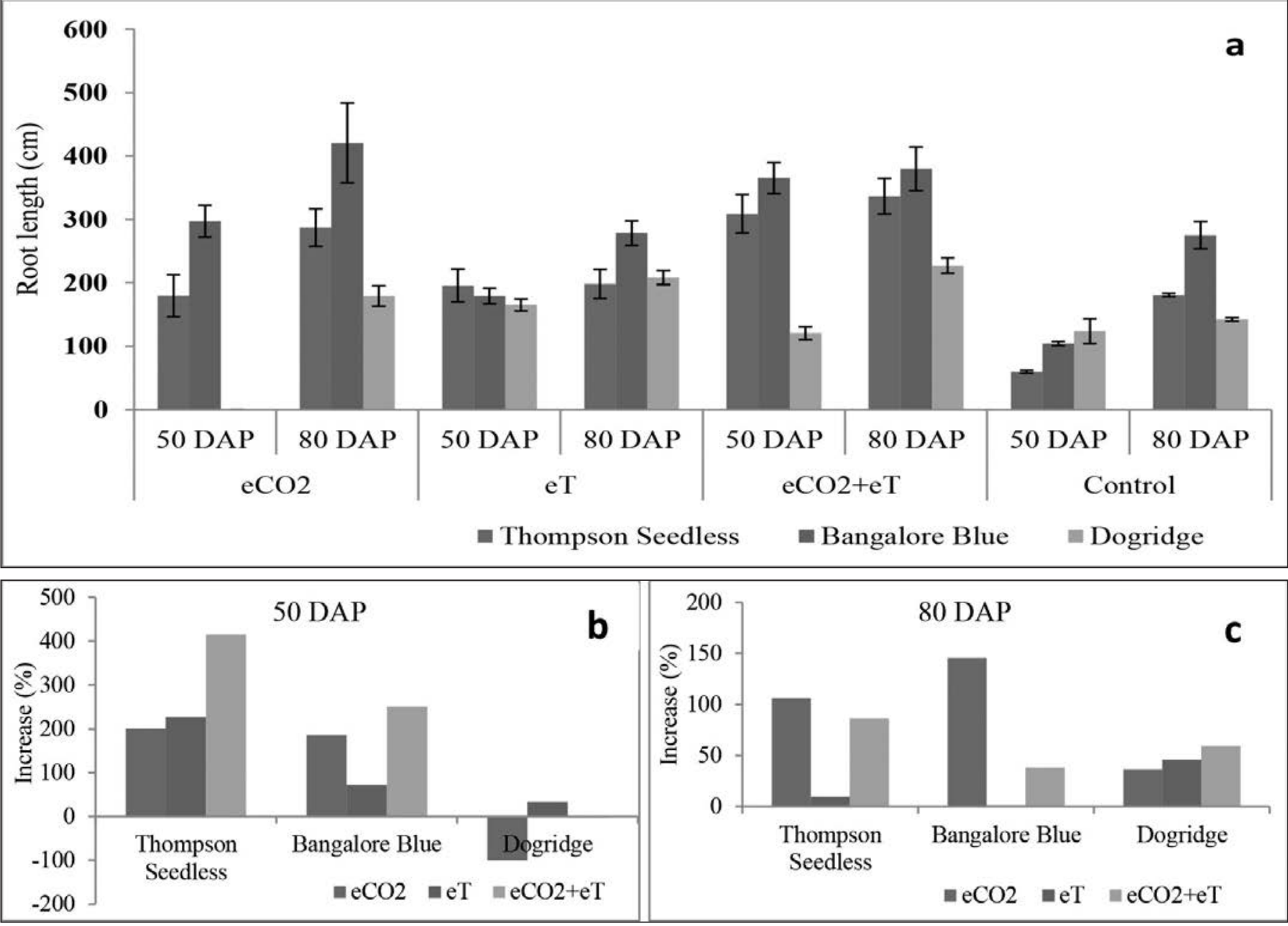

Fig. 2: (a) Total root length of grape varieties under $\mathrm{eCO}_{2}$, eT, $\mathrm{eCO}_{2}+\mathrm{eT}$ and control conditions at 50 and $80 \mathrm{DAP}$; Percentage increase in root length over control (b). at 50 DAP and (c). at 80 DAP

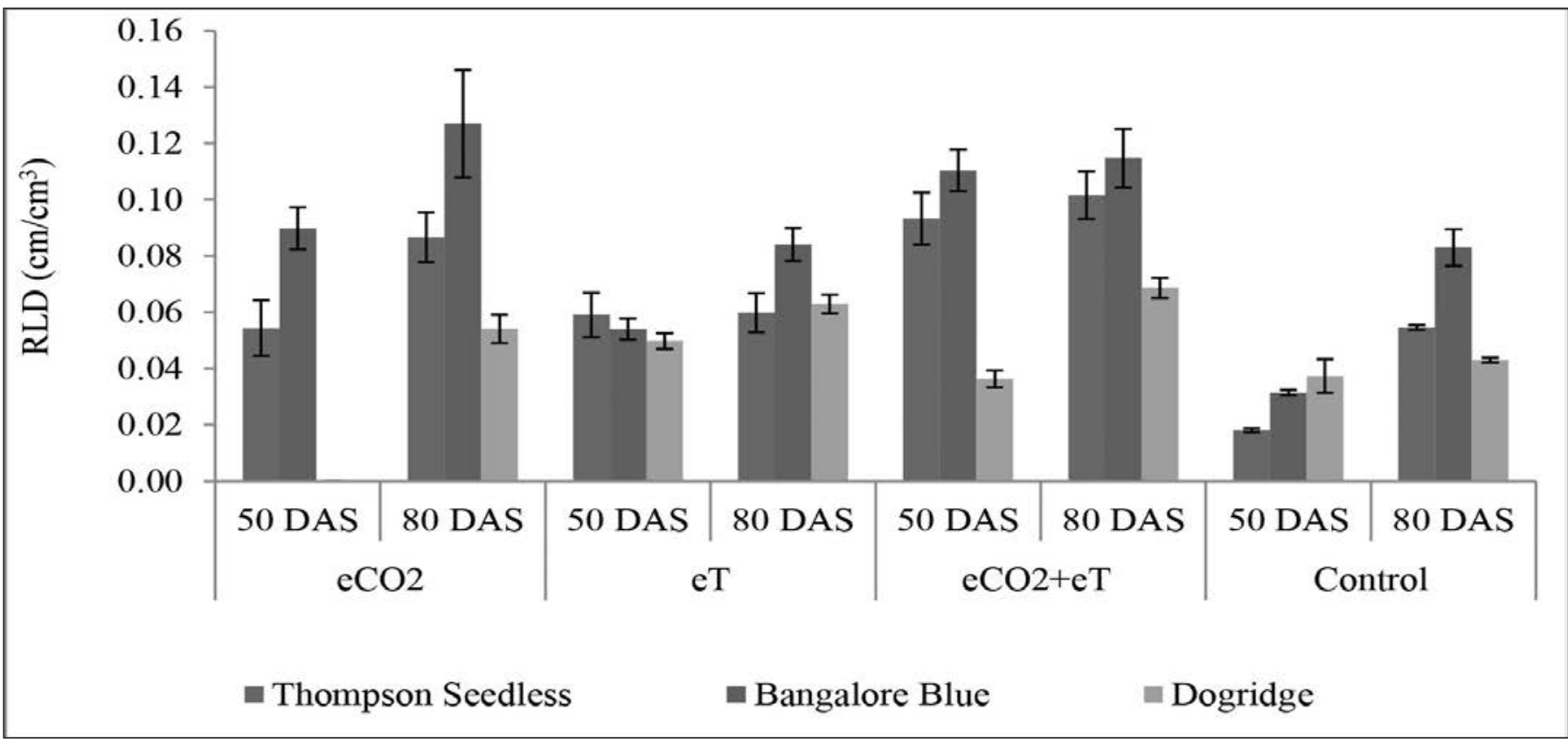

Fig. 3: Root Length Density of grape varieties to different treatments at 50 and 80 DAP 

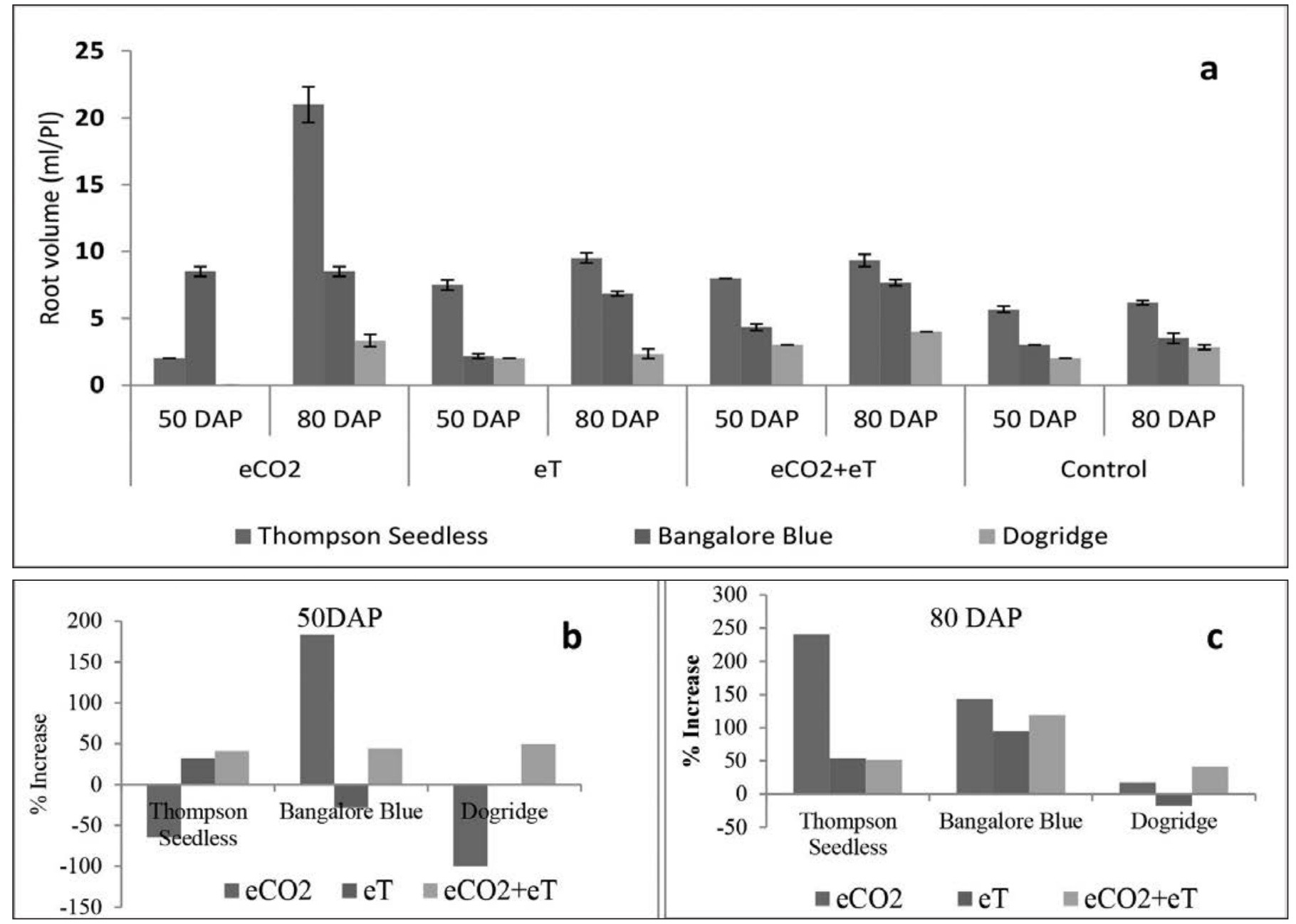

Fig 4: (a) Total root volume of grape varieties under $\mathrm{eCO}_{2}$, eT, $\mathrm{eCO}_{2}+\mathrm{eT}$ and control conditions at 50 and 80 DAP; Percentage increase in root volume over control (b). at 50 DAP and (c). at 80 DAP

shown higher root length under eT $(165.0 \pm 9.2 \mathrm{~cm})$. At 80 DAP Thompson Seedless $(336.6 \pm 27.8 \mathrm{~cm})$ and Dogridge $(227.2 \pm 12.1 \mathrm{~cm})$ has shown highest root length under $\mathrm{eCO}_{2}+\mathrm{eT}$, while Bangalore Blue under $\mathrm{eCO}_{2}(420.5 \pm 63.1$ cm) (Fig. 2a)

At 50 DAP, Thompson Seedless has shown an increase in total root length of 200, 226.4 and $415.5 \%$ under $\mathrm{eCO}_{2}$, eT and $\mathrm{eCO}_{2}+\mathrm{eT}$ respectively over control while it was $185.3,71.8$ and $250.1 \%$ respectively with Bangalore Blue. (Fig. 2b).

At 80 DAP, all the three varieties has shown an increase in root length under three treatments over control. Increase in root length was 106.3, 9.6 and $86.1 \%$ under $\mathrm{eCO}_{2}$, eT and $\mathrm{eCO}_{2}+\mathrm{eT}$ respectively with Thompson Seedless over control, while it was 145.4, 1.1 and $38.1 \%$ for Bangalore Blue and 36.6, 46.1 and $59.4 \%$ for Dogridge respectively (Fig. 2c). This clearly indicating that individual condition of $\mathrm{eCO}_{2}$ promoted higher root length while eT showed very less impact especially in Thompson Seedless and Bangalore Blue and the combined conditions of $\mathrm{eCO}_{2}$ and eT also improved the root length though with lesser magnitude, indicating the impact of $\mathrm{eCO}_{2}$ even at higher temperature on this trait. Though Dogridge registered no response for root length under $\mathrm{eCO}_{2}$ recorded better response under eT and $\mathrm{eCO}_{2}+\mathrm{eT}$ revealing its tolerance to higher temperature.

Wang et al. (2013) recorded increased root length in tomato at elevated $\mathrm{CO}_{2}$ than ambient $\mathrm{CO}_{2}$ condition. Davis and Potter (1983) observed that elevated $\mathrm{CO}_{2}$ increased root length and dry weight of several ornamentals.

\section{Root length density $\left(\mathrm{cm} \mathrm{cm}^{-3}\right)$}

Thompson Seedless has shown higher RLD under $\mathrm{eCO}_{2}+\mathrm{eT}$ at 50 DAP $(0.09 \pm 0.01)$ and 80 DAP $(0.10 \pm 0.01)$, while Bangalore Blue has shown higher RLD under $\mathrm{eCO}_{2}+\mathrm{eT}(0.11 \pm 0.01)$ at 50DAP, and under 

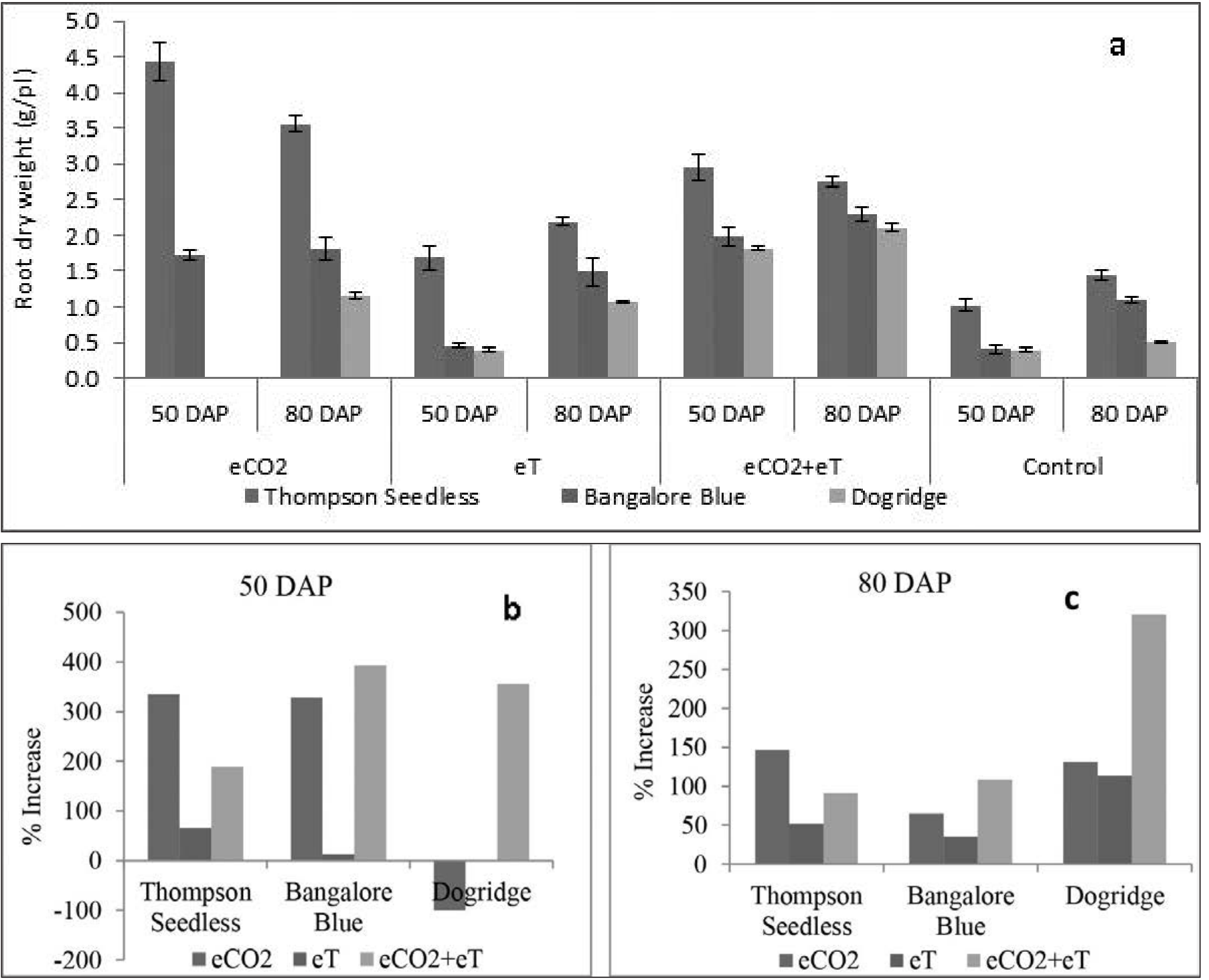

Fig 5: (a) Total root dry weight of grape varieties under $\mathrm{eCO}_{2}$, eT, eCO $+\mathrm{eT}$ and control conditions at 50 and $80 \mathrm{DAP}$; Percentage increase in root dry weight over control (b). at 50 DAP and (c). at 80 DAP

$\mathrm{eCO}_{2}(0.13 \pm 0.02)$ at 80DAP. However, Dogridge has shown higher RLD under eT $(0.05 \pm 0.00)$ at 50DAP, and under $\mathrm{eCO}_{2}+\mathrm{eT}(0.07 \pm 0.00)$ at $80 \mathrm{DAP}$ (Fig. 3).

Among the three varieties, Bangalore Blue has shown higher RLD than Thompson Seedless and Dogridge under all the treatments. This may be because of the difference in root system of Bangalore Blue like having more root length, producing a greater number of roots, and production of number secondary roots and root hairs. From these results it can be concluded that RLD is higher when cuttings exposed to $\mathrm{eCO}_{2}$ alone or in combination with high temperature $\left(\mathrm{eCO}_{2}+\mathrm{eT}\right)$.

\section{Root volume $\left(\mathrm{ml} \mathrm{pl}^{-1}\right)$}

At 50 DAP, Thompson Seedless has shown higher root volume under $\mathrm{eCO}_{2}+\mathrm{eT}(8.0 \mathrm{ml} / \mathrm{pl})$. Though the root volume of Thompson Seedless was less under $\mathrm{eCO}_{2}$ at 50DAP $(2.0 \mathrm{ml} / \mathrm{pl})$, however by $80 \mathrm{DAP}$ it was highest $(21.0 \mathrm{ml} / \mathrm{pl})$. In Bangalore Blue the root volume was highest under $\mathrm{eCO}_{2}$ and similar $(8.5 \pm 0.37)$ at both 50 and 80 DAP. While in Dogridge highest root volume was under $\mathrm{eCO}_{2}+\mathrm{eT}$ at $50(3.0 \pm 0.0)$ and $80(4.0 \pm 0.0)$ DAP. Under $\mathrm{eCO}_{2}$ and control conditions there was no significant difference in root volume of Bangalore Blue at 50 and 80 DAP, whereas a significant difference plants under eT and $\mathrm{eCO}_{2}+\mathrm{eT}$ shown at 50 and $80 \mathrm{DAP}$. At final sampling Thompson Seedless has shown higher root volume under all the three treatments (Fig. 4a) as compared with ambient control.

At 50 DAP, Thompson Seedless and Dogridge has shown a decrease of 64.7 and $100 \%$ in root volume under $\mathrm{eCO}_{2}$, whereas Bangalore Blue has shown an increase of 
183.3\% over control. While under eT Thompson Seedless has recorded an increase of $32.4 \%$ in root volume over control, whereas Bangalore Blue has shown a decrease of $27.8 \%$. The root volume of Dogridge under eT and control plants was similar. At $\mathrm{eCO}_{2}+\mathrm{eT}$, an increase of 41 , 44, 50\% was recorded by Thompson Seedless, Bangalore Blue, Dogridge respectively over control (Fig.4b).

At 80 DAP, Thompson Seedless, Bangalore Blue and Dogidge has shown an increase of 240, 54 and 51\% in root volume under $\mathrm{eCO}_{2}$ over control. While under $\mathrm{eT}$, Thompson Seedless and Bangalore Blue has shown an increase of 54 and $95 \%$ of root volume respectively over control while Dogridge has shown a decrease of $18 \%$. Under $\mathrm{eCO}_{2}+\mathrm{eT}$ Thompson Seedless, Bangalore Blue and Dogidge has shown an increase of 51, 119 and 41\% in root volume over control (Fig. 4c).

\section{Dry weight of roots $\left(\mathrm{g} \mathrm{pl}^{-1}\right)$}

Maximum root biomass of Thompson Seedless (4.4 \pm 0.27$)$ and Bangalore Blue $(1.7 \pm 0.07)$ has shown under $\mathrm{eCO}_{2}$, while Dogridge has shown the highest root biomass under $\mathrm{eCO}_{2}+\mathrm{eT}(0.8 \pm 0.03)$ at $50 \mathrm{DAP}$. At 80 DAP Thompson Seedless (3.6 \pm 0.12$)$ and Dogridge $(1.2 \pm 0.05)$ roots have shown maximum dry weight under $\mathrm{eCO}_{2}$, however Bangalore Blue has shown maximum root biomass under $\mathrm{eCO}_{2}+\mathrm{eT}(2.3 \pm 0.10)$. Among the selected three different varieties, maximum biomass was accumulated by Thompson Seedless and lowest by Dogridge under all the four treatments at both 50 and 80DAP while plants under ambient condition recorded lowest biomass in all the three varieties (Fig. 5a).

At 50 DAP there was an increase of 334, 65 and $189 \%$ root biomass over the control under $\mathrm{eCO}_{2}$, eT and $\mathrm{eCO}_{2}+\mathrm{eT}$ respectively in Thompson Seedless, while in Bangalore Blue there was an increase of root biomass of 328, 12 and 393\% under $\mathrm{eCO}_{2}$, eT and $\mathrm{eCO}_{2}+\mathrm{eT}$ respectively over control. Dogridge has shown an increase of $356 \%$ root biomass over control under $\mathrm{eCO}_{2}+\mathrm{eT}$. The root dry weights of Dogridge plants grown under eT and control were similar (Fig.5b).

At 80 DAP, all the three varieties has shown an increase of dry weight at all the three treatments viz., $\mathrm{eCO}_{2}$, eT, and $\mathrm{eCO}_{2}+\mathrm{eT}$ over control. Thompson Seedless has shown an increase of 146, 52 and $91 \%$ under $\mathrm{eCO}_{2}$, $\mathrm{eT}$ and $\mathrm{eCO}_{2}+\mathrm{eT}$ respectively, while in Bangalore Blue there was an increase of 65,35 and $105 \%$ under $\mathrm{eCO}_{2}$, $\mathrm{eT}$ and $\mathrm{eCO}_{2}+\mathrm{eT}$ respectively. While Dogridge has shown an increase of $131 \%$ of root dry mass under $\mathrm{eCO}_{2}$ over control. A 113 and 320\% increase in root dry mass of Dogridge was observed under eT and $\mathrm{eCO}_{2}+\mathrm{eT}$ over control (Fig. 5c). At final sampling, all the treatments have shown an increase of root dry mass over control. Under $\mathrm{eCO}_{2}$, Thompson Seedless has shown maximum root dry weight, while Dogridge under eT and $\mathrm{eCO}_{2}+\mathrm{eT}$.

The dry matter accumulation is resultant effect of enhanced plant growth characters and greater photosynthetic accumulation. The amount of dry matter produced depends on the better photosynthesis obtained by large and efficient assimilating area, adequate supply of solar radiation, carbon dioxide, favourable environmental condition and efficient utilization of nutrients (Reddy et al., 1994). Many studies have observed a greater root biomass under elevated $\mathrm{eCO}_{2}$ (Chaudhuri et al., 1990, Acock et al., 1990; Weigel et al., 1994). In 2013-15, on experiments with Valeriana jatamansi, Kaundal and Kumar (2020) found Elevated $\mathrm{CO}_{2}$ significantly enhanced root biomass of Valeriana jatamansi. The results are in line with earlier reports on different plant species where Goudriaan and Ruiter (1983) found that doubling of $\mathrm{eCO}_{2}$ had the largest effect on dry matter production provided nutrient supply is not limiting.

\section{CONCLUSION}

The eT condition reduced all the root parameters, their performance improved under $\mathrm{eCO}_{2}+\mathrm{eT}$ indicating the presence of higher concentration of $\mathrm{CO}_{2}$ reduced the ill effects of high temperature. Overall, $\mathrm{eCO}_{2}$ and $\mathrm{eCO}_{2}+\mathrm{eT}$ conditions improved root parameters of grape varieties, while eT reduced them as compared to their performance under ambient condition and varietal variation happen to be significant. The amount of dry matter produced depended upon the better photosynthesis obtained by large and efficient assimilating area, adequate supply of solar radiation, carbon dioxide, favourable environmental condition and efficient utilization of nutrients.

\section{ACKNOWLEDGEMENTS}

The authors like to acknowledge the support and facilities provided by ICAR-CRIDA specially Crop Science Division for their help during experimental study.

Conflict of Interest Statement : The author(s)declare(s) that there is no conflict of interest.

Disclaimer : The contents, opinions, and views expressed in the research article published in the Journal of Agrometeorology are the views of the authors and do not necessarily reflect the views of the organizations they belong to.

Publisher's Note : The periodical remains neutral with regard to jurisdictional claims in published maps and 
institutional affiliations.

\section{REFERENCES}

Acock, B., Acock, M.C. and Pasternak, D. (1990). Interactions of $\mathrm{CO}_{2}$ enrichment and temperature on carbohydrate production and accumulation in musk melon leaves. J. Amer. Soc. Hort. Sci., 115:525-529.

Bowes, G. (1993). Facing the inevitable plants and increasing atmospheric $\mathrm{CO}_{2}$. Ann. Rev. Plant Physiol. Plant Mol. Biol., 44:309-332.

Chaudhuri, U.N., Burnett, R.B., Kirkham, M.B. and Kanemasu E.T. (1986). Effect of carbon dioxide on sorghum yield, root growth and water use. Agric. For. Meteorol., 37:109-122.

Chaudhuri, U.N., Kirkham, M.B. and Kanemasu E.T. (1990). Root growth of winter wheat under elevated carbon dioxide and drought. Crop Sci., 30:853-857.

Davis, T.D. and Potter, J. R. (1983). High $\mathrm{CO}_{2}$ applied to cuttings: Effects on rooting and subsequent growth in ornamental species. J. Hort. Sci., 18: 194-196.

Goudriaan, J. and de Ruiter, H.E. (1983). Plant growth in response to $\mathrm{CO}_{2}$ enrichment, at two levels of nitrogen and phosphorus supply. 1 . Dry matter, leaf area, and development. Netherlands J. Agric. Sci., 31: 157-169.

Inter-Governmental Panel on Climate Change (2007): Synthesis report. Summary for policy makers. www.ipcc.ch/pdf/assessment report/ar4/syr/ar4_ ar4_syr_spm. pdf.

Inter-Governmental Panel on Climate Change (IPCC). (2014). Climate Change 2014: Summary. Report of the IPCC. Cambridge University Press, Cambridge, UK.

Kadbhane, S.J. and Manekar, V.L. (2020). Development of agro-climatic grape yield model for Nashik region, Maharashtra, India. J. Agrometeorol., 22, (4): 494-500

Kaundal, M. and Kumar, R. (2020). Effect of elevated $\mathrm{CO}_{2}$ and elevated temperature on growth and biomass accumulation in Valeriana jatamansi Jones under different nutrient status in the western Himalaya. J. Agrometeorol., 22 (4): 419-428.

Kimball, B.A., Kobayashi, K. and Bindi, M. (2002). Responses of agricultural crops to free air $\mathrm{CO}_{2}$ enrichment. Adv. Agron., 77: 293-368.

Madhu, M. and Jerry, L. (2015). Elevated Carbon Dioxide and Soil Moisture on Early Growth Response of Soybean. Agric. Sci., 6: 263-278.

Mullins, M.G., Bouquet, A. and Williams, L.E. (1992). Developmental physiology: The vegetative grapevine. In: Biology of the grapevine, Cambridge Univ. Press, New York, pp. 80-111.

Norby, R.J., Cotrufo, M.F., Ineson, P., O’Neill, E.G. and Canadell, J.G. (2001). Elevated $\mathrm{CO}_{2}$, litter chemistry, and decomposition: a synthesis. Oecologia 127: 153-165.

Pritchard, S.G. and Amthor, J.S. (2005). Crops and Environmental Change: An Introduction to Effects of Global Warming, Increasing Atmospheric $\mathrm{CO}_{2}$ and $\mathrm{O}_{3}$ Concs, and Soil Salinization on Crop Physiology and Yield, Food Products, The Haworth Press, NY.

Rajkumar, M., Prasad, M.N.V., Sandhya, S. and Freitas, H. (2013). Climate change driven plant-metalmicrobe interactions. Environ. Int., 53: 74-86.

Reddy, V.R., Reddy, K.R., Acock, M.C. and Trent, A. (1994). Carbon dioxide enrichment and temperature effects on root growth in cotton. Biotronics, 23: 47-57.

Rogers, H.H., Runion, G.B. and Krupa. S.V. (1994). Plantresponses to atmospheric $\mathrm{CO}_{2}$ enrichment with emphasis on roots and the rhizosphere. Environ. Poll., 83:155-189.

Wang, H., Xiao, W., Niu. Y., Jin, C., Chai, R., Tang, C. and Zhang, Y. (2013). Nitric oxide enhances development of lateral roots in tomato (Solanum lycopersicum L.) under elevated carbon dioxide. Planta, 237: 137-144.

Weigel, H.J., Manderscbeid, R., Jager, H.J. and Mejer, G.J. (1994). Effects of season-long $\mathrm{CO}_{2}$ enrichment on cereals. I. Growth performance and yield. Agr. Ecosyst. Environ., 48: 231-240. 